\title{
ANALISIS KEMAMPUAN DAYA GABUNG GEN PADA GENOTIPE UDANG GALAH UNTUK MENDUKUNG PROGRAM SELEKSI DAN HIBRIDISASI
}

\author{
Wartono Hadie"), Subandriyo"', Lies Emmawati Hadie"), dan Ronny Rachman Noor"')
}

\begin{abstract}
ABSTRAK
Penelitian tentang daya gabung gen (combining ability) dilakukan dengan mengunakan tiga strain udang galah yakni Musi, Barito, dan GIMacro. Perkawinan dilakukan secara fullsib di dalam dan di antara strain serta menghasilkan sembilan kombinasi genotipe. Keturunan dari masingmasing perkawinan dibesarkan pada lingkungan salinitas $0 \%$, $10 \%$, dan $15 \%$. Parameter genetik berupa specific combining ability (SCA), general combining ability (GCA), heterosis, dan resiprok dianalisis dengan menggunakan karakter bobot badan. Hasil yang diperoleh memperlihatkan bahwa nilai GCA tertinggi dimiliki oleh strain GIMacro. Persilangan GIMacro dengan Musi demikian juga dengan resiproknya memberikan hasil yang lebih baik dibanding jika disilangkan dengan Barito. Adanya pengaruh dari kecocokan gen dari masing-masing genotipe, heterosis yang terbesar pada F1 adalah genotipe Musi dan Barito.
\end{abstract}

ABSTRACT: Analysis of combining ability among genotype of Macrobrachium rosenbergii to support selection and hybridization program. By: Wartono Hadie, Subandriyo, Lies Emmawati Hadie, and Ronny Rachman Noor

Research on the combining ability of three different strains i.e. Musi, Barito, and GI Macro have been conducted. Full sib mating design conducted inter and intra strain resulted nine combinations of genotype. The set of relative resulted from those mating were reared in the three different levels of salinity i.e. $0 \%, 10 \%$, and $15 \%$. Genetic parameters such as general combining ability (GCA), specific combining ability (SCA), reciproc, and heterosis were analyzed using the trait of body weight. The result shows that the highest of GCA is GIMacro, while the SCA is combination between Musi and Barito. The highest heterosis in F1 generation reached by Musi and Barito combinations as the effect of gene matching occation between genotype.

KEYWORDS: general combining ability, specific combining ability, heterosis, Macrobrachium rosenbergii

\section{PENDAHULUAN}

Secara genetik persilangan akan menaikkan heterosigositas, sehingga dengan demikian menaikkan keragaman genetik (Hardjosubroto, 1994). Oleh karena itu, tujuan utama dari persilangan adalah menggabungkan dua atau lebih sifat yang berbeda yang semula berada pada strain yang berbeda kedalam suatu hasil silangan. Selain itu, dapat pula dipakai sebagai alat untuk menghasilkan galur baru, atau pemanfaatan heterosis. Beberapa hal yang perlu difahami adalah daya gabung gen (combining ability), daya gabung secara spesifik, resiprok, dan heterosis.

Daya gabung gen adalah kemampuan suatu genotipe untuk menyatukan konfigurasi gennya dengan genotipe lain untuk membentuk/menghasilkan suatu keragaan spesifik yang lebih baik. Kemampuan demikian bisa sangat beragam di antara genotipe, oleh karena itu, daya gabung gen pada prinsipnya adalah varian dari antara persilangan. Daya gabung umum (general combining ability/GCA) menurut Falconer \& Mackay (1996), adalah suatu simpangan dari rataan semua persilangan yang dibentuk. Daya gabung khusus (specific combining ability/SCA) adalah interaksinya. Menurut Mukerjee (2001), SCA adalah heterosis individu, karena merupakan gabungan konfigurasi gen dua individu secara khusus. Untuk dapat menghitung daya gabung tersebut digunakan disain perkawinan dua arah (diallele crosses) ataupun perkawinan terpola antara satu strain dengan sejumlah strain lainnya (pedigreed crossing).

Dengan silang dua arah menurut Singh \& Chaudhary (1977), dapat diperoleh dugaan potensigen masing-masing strain, tren hasil persilangan antar

*) Peneliti pada Pusat Riset Perikanan Budidaya, Jakarta

${ }^{\star \star}$ ) Peneliti pada Balai Penelitian Ternak Ciawi, Bogor

***) Fakultas Peteinakan Institut Pertanian Bogor 
individu tertentu yang dinyatakan sebagai daya gabung khusus (SCA), dan tren hasil dari persilangan antar strain yang dinyatakan dalam bentuk daya gabung umum (GCA).

Heterosis adalah perbedaan antara rataan hasil keturunan dari suatu persilangan dengan rataan dari hasil tetuanya (Warwick et al., 1995). Dalam suatu keadaan keturunan dapat melebihi rataan kedua tipe tetuanya dan dalam keadaan lain keturunan dapat melebihi rataan dari tetuanya, tapi bukan kedua tipe tetuanya.

Pada umumnya heterosis dipengaruhi oleh efek dominan, pengaruh demikian dapat digunakan untuk menjelaskan ekspresi fenotipe hibrida yang dikontrol oleh beberapa faktor genetik. Faktor tersebut adalah pengaruh gen aditif, pengaruh gen maternal, heterosis individu yang juga dapat dinyatakan sebagai specific combining ability dan pengaruh epistasis (Tave, 1986).

Udang galah hidup dalam lingkungan media yang berbeda selama siklus hidupnya. Tampak adanya pemisahan yang nyata antara stadia larva yang memerlukan lingkungan dengan salinitas $12 \%$ o- $25 \%$. dengan stadia dewasa yang memerlukan lingkungan air tawar (Ling, 1969). Kematian udang galah yang dipelihara hingga ukuran konsumsi dapat mencapai $75 \%$ dan pada tahap aklimatisasi dalam salinitas adalah yang terbesar, sisanya adalah kematian selama masa pemeliharaan (New, 1995).

Pada pemeliharaan dari $\mathrm{PL}$ hingga dewasa diperlukan suhu $29^{\circ} \mathrm{C}-31^{\circ} \mathrm{C} ; \mathrm{O}_{2} 6-8 \mathrm{mg} / \mathrm{L} ; \mathrm{pH} 7-$ 8,5 ; kesadahan $<140 \mathrm{mg} / \mathrm{L} \mathrm{CaCO}$. Salinitas yang dapat ditoleransi udang galah dan hidup dengan normal adalah 16\% (Popper \& Davidson, 1981) dan mencapai bobot $26 \mathrm{~g}$ selama delapan bulan. Sementara itu menurut Smith et al. (1975) kondisi optimal untuk pertumbuhan udang galah adalah $5 \%-10 \%$. Tetapi menurut Hadie et al. (2001) laju pertumbuhan pada air payau dengan salinitas $10 \%-15 \%$ o secara signifikan lebih rendah dibandingkan dengan yang dipelihara pada air tawar.

Terdapat perbedaan genetik secara nyata antara populasi udang galah yang diuji berdasarkan frekuensi haplotypenya $(P<0,05)$. Perbedaan ini disebabkan udang galah dari Barito mempunyai major composite haplotype yang berbeda dengan udang galah dari Musi dan GIMacro. Selanjutnya, jika major composite haplotype terkait pada karakter pertumbuhan, di mana udang galah GIMacro mempunyai laju pertumbuhan yang lebih baik sekitar 30\% (Hadie \& Hadie, 1999), dapat diduga bahwa haplotipe 1 dan 4 udang galah GIMacro (mendominasi sekitar 50\% dari total frekuensi haplotipe) berasal dari populasi Citanduy dan Citarum, sedangkan haplotipe 2 dan 3 udang galah GIMacro (mendominasi sekitar $44 \%$ dari total frekuensi haplotipe) berasal dari populasi Musi (Nugroho et al., 2003).
Penelitian ini bertujuan untuk menganalisis kemampuan daya gabung gen secara umum (GCA), daya gabung secara khusus (SCA), resiprok, dan hibryd vigor dari tiga genotipe udang galah.

\section{BAHAN DAN METODE}

Induk yang digunakan dalam penelitian ini adalah tiga strain udang galah yang berasal dari populasi Sungai Musi, Barito, dan GIMacro. Pemilihan strain didasarkan pada pertimbangan bahwa populasi tersebut masih memiliki keragaman genetik yang tinggi, sedangkan GIMacro adalah sebagai varietas yang telah terseleksi yang ingin diperbaiki keragaannya. Hasil persilangan yang dibuat dibesarkan dalam salinitas yang berbeda yaitu $0 \%, 10 \%$, dan $15 \%$.

Strain Sungai Musi diambil dari daerah Talangfatima $\pm 50 \mathrm{~km}$ dari laut. Strain Sungai Barito, diambil dari daerah Margasari, anak Sungai Barito $\pm 70 \mathrm{~km}$ dari laut. GIMacro adalah varietas baru udang galah yang merupakan populasi sintetik dari strain Citanduy, Cimanuk, dan Musi (Hadie et al., 2001).

Masing-masing induk dari populasi yang berbeda digunakan tag dengan nomor untuk mempermudah manajemen dan perkawinan. Jenis tag terbuat dari lempeng plastik bernomor dengan pengikat benang elastik, dan jarum. Tag dipasang di pertengahan antara chephalothorax (kepala) dan abdomen (badan) yang merupakan daerah moulting line.

Perkawinan dilakukan secara full sib sebanyak lima pasangan dari setiap strain, untuk membentuk $\mathrm{G}_{1}$ dan dicatat nomor tag yang digunakan dalam perkawinan (Tabel 1). Induk-induk yang dipasangkan dipilih dari induk betina yang telah matang gonad, yaitu yang berwarna merah jingga pada bagian kepala arah dorsal. Induk demikian kemudian dipasangkan satu jantan satu betina dalam satu wadah.

Larva yang diperoleh dari setiap pasangan dipelihara secara terpisah menggunakan metode air jernih tanpa plankton (clear water system) dengan

Tabel 1. Skema perkawinan udang galah (dialelle crosses) dari strain Musi, Barito, dan GIMacro

Table 1. Dialelle crosses mating design of giant freshwater prawn from Musi, Barito, and GIMacro

\begin{tabular}{lccc}
\hline \multicolumn{1}{c}{ O $^{\prime \prime}$} & $\begin{array}{c}\text { Musi } \\
\text { (M) }\end{array}$ & $\begin{array}{c}\text { Barito } \\
\text { (B) }\end{array}$ & $\begin{array}{c}\text { GI Macro } \\
\text { (G) }\end{array}$ \\
\hline Musi (M) & MM & MB & MG \\
Barito (B) & BM & BB & BG \\
GI Macro (G) & GM & GB & GG \\
\hline
\end{tabular}


kepadatan 100 ekor/liter. Bak larva yang digunakan adalah fiber glass berbentuk kerucut. Salinitas media selama pemeliharaan larva hingga PL digunakan $12 \%$ - $15 \%$ secara tetap. Selama pemeliharaan larva hingga PL mencapai \pm 30 hari, digunakan pakan alami dan pakan buatan. Pakan alami berupa nauplii Artemia dengan ransum 5-45 nauplii per ekor larva per hari. Pakan buatan terbuat dari tepung terigu, tepung susu tanpa lemak (non fat), daging ikan, telur ayam, vitamin, dan mineral. Formulasi seperti kue, kemudian dikukus hingga masak dan disimpan di kulkas untuk mencegah kerusakan sebelum digunakan (Aquacop, 1983).

Pembesaran pasca larva $(P L)$ yang dihasilkan dari pemeliharaan larva kemudian dibesarkan di dalam media bersalinitas $0 \%, 10 \%, 15 \%$ sesuai plot perlakuan masing-masing di tambak. Masing-masing plot berukuran $2 \times 25 \mathrm{~m}^{2}$ dengan kedalaman air 80 $\mathrm{cm}$ sebanyak 135 buah. Pakan yang diberikan pada PL hingga dewasa adalah pakan standar komersial berupa pelet (UG 800; UG 801; UG 802; UG 803). Pakan diberikan sebanyak tiga kali sehari dengan ransum $3 \%-5 \%$ bobot badan per hari. Salinitas selama pemeliharaan dipertahankan sesuai perlakuan dengan kisaran $\pm 2 \%$.

Data yang dikumpulkan meliputi bobot udang galah sebagai parameter utama. Analisis statistik meliputi: specific combining ability (SCA), general combining ability (GCA), resiprok, dan heterosis. Rancangan analisis data yang diperoleh masing-masing:

1.Daya gabung gen (combining ability) dianalisis dengan menggunakan prinsip Singh \& Chaudhary (1977) dengan menggunakan lima langkah sebagai berikut:

a. Anova combining ability komponen varian meliputi $S S_{g c a^{\prime}} S S_{s c a^{\prime}} S S_{\text {resiprok, }}$ dan $S S_{\text {error }}$

b. Pendugaan komponen varian

$$
\begin{aligned}
& \sigma_{g}^{2}=\frac{1}{2 n}\left[\frac{M^{\prime} e+n(n-1) M s}{n^{2}-n+1}\right] \\
& \sigma_{s}^{2}=\frac{n^{2}}{2\left(n^{2}-n+1\right)}\left(M s-M^{\prime} e\right) \\
& \sigma_{r}^{2}=\frac{1}{2}\left(M r-M^{\prime} e\right)
\end{aligned}
$$

c. Pengaruh general combining ability $\left(G_{i}\right)$

$$
G_{i}=\frac{1}{2 n}(Y i . Y . i)-\frac{1}{n^{2}} Y . .
$$

d. Pengaruh specific combining ability $\left(\mathrm{S}_{\mathrm{i}}\right)$

$$
S_{l y}=\frac{1}{2}(Y i j+Y j i)-\frac{1}{2}(Y i .+Y . i+Y j .+Y . j)+\frac{1}{n^{2}} Y
$$

e. Pengaruh reciprocal $\left(R_{i i j}\right)$

$$
R_{i j}=\frac{1}{2}(Y i j-Y j i) R_{i j}
$$

di mana:

$\sigma_{g}^{2}=$ komponen varian $\mathrm{GCA}$

$\sigma_{s}^{2}=$ komponen varian SCA

$\sigma_{r}^{2}=$ komponen varian resiprok

M'e $=$ error

Ms $=$ rataan SCA

$\mathrm{Mr}=$ rataan resiprok

$\mathrm{n}=$ ulangan

$Y_{i}=$ total variabel perlakuan

$Y_{j}=$ total variabel ulangan

2. Heterosis dihitung dengan menggunakan prinsip Tave (1996); Warwick et al. (1995):

$\% H=\frac{P_{\text {Silangan }}(A B+B A)-P_{\text {Tetua }}(A A+B B)}{P_{\text {Teua }}(A A+B B)} \times 100 \%$

di mana:

$\% \mathrm{H} \quad=$ Koefisien heterosis

$(A A+B B)=$ Keragaan karakter bobot badan tetua

$(A B+B A)=$ Keragaan karakter bobot badan silangan (progeny)

3. Standard error (SE) dianalisis dengan metode Becker (1984) sebagai berikut:

$$
S E=\sqrt[4]{\frac{2(1-t)^{2}[1+(k-1)]^{2}}{k(k-1)(s-1)}}
$$

di mana:

$\mathrm{k}=$ jumlah progeni yang digunakan

$s=$ sire

$\mathrm{t}=$ korelasi interkelas

\section{HASIL DAN BAHASAN}

Hasil persilangan antar genotipe baik di dalam maupun antar strain memberikan gambaran tentang potensi gen masing-masing strain dan juga keunggulan dari hasil penggabungan gen tersebut. Dari hasil persilangan ini dapat dihitung daya gabung gen umum (general combining ability), daya gabung khusus (specific combining ability), dan heterosisnya. 


\section{Daya Gabung Gen}

Berdasarkan analisis ragam dapat ditentukan pola penggabungan gen antar strain. Daya gabung umum (GCA), daya gabung gen secara khusus (SCA), dan resiproknya berasal dari rataan bobot udang galah hasil persilangan dua arah seperti yang dapat dilihat pada Tabel 2. Genotipe GG memiliki daya gabung gen tertinggi dari total semua salinitas dibanding genotipe BB dan MM. Demikian pula daya gabung khusus (SCA) untuk persilangan dengan unsur genotipe GG memberikan hasil yang lebih tinggi dibanding persilangan tanpa GG. Pada silang balik (resiprok) juga terlihat bahwa genotipe MG memiliki nilai tertinggi, artinya bahwa sifat paternal GG sangat mendukung pertumbuhan pada persilangan tersebut.

Penggabungan gen melalui persilangan acak yang dilakukan dalam penelitian ini dimaksudkan untuk mencari peluang genotipe mana yang menghasilkan keturunan terbaik (Falconer \& Mackay, 1996) karena gamet-gamet dalam kelompok tersebut tidak berbeda nyata. SCA adalah heterosis individu (Mukerjee, 2001) karena hasilnya bergantung dari kecocokan konfigurasi gen (harmonisasi gen) dari kedua individu induk yang terekspresi pada progeninya.

Nilai-nilai harapan dari penghitungan pada Tabel 2 dapat positif ataupun negatif (Singh \& Chaudhary, 1977). Hasil ini merupakan gambaran kecocokan kombinasi dari konfigurasi gen antar kelompok (GCA), antar individu (SCA), dan kemungkinan silang baliknya (resiprok). Genotipe GG mempunyai daya gabung terbesar di antara tiga strain yang digunakan, berarti mempunyai potensi genetik yang baik untuk dieksploitasi dalam mendukung laju pertumbuhan. Selanjutnya disusul secara berturut-turut strain Musi dan Barito. Hasil ini sesuai dengan hasil pemindahan DNA oleh Nugroho et al. (2004).

Kesesuaian dalam penggabungan gamet-gamet dalam persilangan yang dipelihara pada salinitas berbeda ditunjukkan dari hasil penghitungan GCA, SCA, dan Resiprok (Tabel 3). Pada unsur GCA terlihat bahwa genotipe GG memiliki nilai tertinggi pada salinitas $0 \%$. Sedangkan pada salinitas $15 \%$, strain MM menjadi yang tertinggi. Nilai resiprok tertinggi untuk salinitas $0 \%$ adalah $M G$, salinitas $10 \%$ genotipe GB dan pada salinitas $15 \%$ adalah BM. GCA untuk genotipe BB tertinggi dimiliki pada salinitas $10 \%$, pada genotipe GG nilai tertinggi pada salinitas $0 \%$ sedangkan pada genotipe MM nilai tertinggi terlihat pada salinitas $15 \%$. Nilai SCA tertinggi dimiliki genotipe GM pada salinitas $0 \%$ sedangkan untuk resiproknya tertinggi pada salinitas $10 \%$.

Nilai-nilai pada Tabel 3 tersebut cukup menarik dan terutama akan lebih berarti lagi, jika masingmasing strain mengekspresikan gen kelenturan adaptif terhadap salinitas pada generasi selanjutnya. $\mathrm{Hal}$ tersebut didukung adanya nilai heritabilitas kelenturan itu sendiri. Pada waktu gen-gen ini terekspresi, terjadi konfigurasi gen pada masingmasing individu, maka pada generasi berikutnya akan berubah sebanding dengan kemajuan seleksi sifat kelenturan yang terjadi.

Tabel 2. Nilai GCA (diagonal), SCA (matriks atas), dan Resiprok (matrik bawah) dari rataan genotipe yang dipelihara semua salinitas

Table 2. Value of GCA (diagonal), SCA (to upper matrix), and reciprocal (left bottom matrix) from body weight means by genotype in all salinity medium levels

\begin{tabular}{cccc}
\hline & B & G & M \\
\hline B & -1.079 & 0.054 & -3.994 \\
G & 0.963 & 1.932 & 0.57 \\
M & 1.86 & 3.99 & -0.721 \\
\hline
\end{tabular}

Tabel 3. Nilai GCA (diagonal), SCA (matriks atas), dan Resiprok (matriks bawah) dari bobot badan genotipe yang dipelihara pada salinitas $0 \%, 10 \%$, dan $15 \%$ o

Table 3. Value of GCA (diagonal), SCA (to upper matrix), and resiprocal (left bottom matrix) from body weight means by genotype in three different salinity levels i.e. 0\%, 10\%, and $15 \%$

\begin{tabular}{|c|c|c|c|c|c|c|c|c|c|}
\hline & \multicolumn{3}{|c|}{ B } & \multicolumn{3}{|c|}{ G } & \multicolumn{3}{|c|}{ M } \\
\hline & $0 \%$ & $10 \%$ & $15 \%$ & $0 \%$ & $10 \%$ & $15 \%$ & $0 \%$ & $10 \%$ & $15 \%$ \\
\hline B & -1.110 & 0.733 & -0.492 & -0.291 & 0.656 & -0.690 & -0.397 & 1.188 & 1.219 \\
\hline G & 0.665 & 0.610 & 0.870 & 1.242 & 0.599 & -0.293 & 2.375 & -0.788 & 0.407 \\
\hline M & -1.895 & -4.840 & 1.110 & 0.695 & 2.830 & -1.000 & -0.133 & -1.332 & 0.285 \\
\hline
\end{tabular}




\section{Heterosis}

Nilai heterosis dari persilangan antar strain antara Musi, Barito, dan GI Macro (Tabel 4) memberikan hasil yang beragam yang dipengaruhi oleh salinitas media pembesaran. Artinya terdapat keragaman nilai heterosis dari setiap persilangan yang dipelihara pada salinitas berbeda. Dari Tabel 4 terlihat bahwa nilai heterosis tertinggi diperoleh pada persilangan MB pada salinitas $15 \%$. Tetapi secara keseluruhan kombinasi MB mempunyai nilai tinggi pada semua salinitas perlakuan dibanding persilangan lain.

Hybrid vigor atau yang lebih dikenal dengan istilah heterosis untuk suatu sifat adalah keunggulan individu hasil persilangan terhadap rataan keragaan galur tetua yang digunakan dalam persilangan tersebut. Harapan dari setiap persilangan adalah diperolehnya individu yang lebih baik keragaannya (misalnya ukuran dan laju pertumbuhan) dibandingkan dengan tetuanya. $\mathrm{Hal}$ tersebut mengingat bahwa di setiap galur sudah terjadi silang dalam dan menfiksasi gen tertentu dalam galur masing-masing dengan kadar yang berbeda dan tidak harus berarti buruk (Warwick et al., 1995). Dengan menyilangkan antar strain tersebut maka akan terjadi suatu kombinasi gen-gen baru yang diharapkan memberikan keragaan yang lebih baik dibanding rataan kedua tetuanya.

Kombinasi gen yang baru sebagai hasil persilangan antar strain akan terbentuk konfigurasi gen baru atau akan menutup gen-gen yang tidak diinginkan. Sebagai hasilnya akan memiliki keragaan yang lebih baik dibanding tetuanya. Silang luar (outbreeding) akan dapat memunculkan heterosigositas yang tertekan pada inbreeding, sehingga bisa meningkatkan fertilitas maupun fitness (Falconer \& Mackay, 1996).

Nilai heterosis dari hasil persilangan antar strain berkisar antara $-15,79 \%$ dan $58,43 \%$. Nilai tersebut menurut Warwick et al. (1995), bisa menggambarkan kecocokan gen di antara genotipe dalam berbagi potensi gen, atau pemunculan sesaat karena adanya perbedaan gen dan akan berubah pada $F_{2}$ dan selanjutnya.

Telah banyak diketahui bahwa beberapa persilangan bangsa atau strain, menghasilkan heterosis lebih besar pada $F_{1}$ dibanding persilangan lain. Namun ada persilangan lain dari galur-galur yang mempunyai keunggulan fenotipe yang sama tapi tidak memberikan hasil yang menguntungkan, kejadian ini disebut nicking atau daya gabung khusus (Warwick et al., 1995). Dengan demikian beberapa persilangan bangsa atau strain, menghasilkan hybrid vigor pada $F_{1}$ yang lebih besar.

Terdapat persilangan yang menghasilkan heterosis yang lebih besar pada $\mathrm{F}_{2}$. Hal tersebut semata-mata menurut Falconer \& Mackay (1996), Warwick et al. (1995) karena kecocokan konfigurasi gen yang dibawa masing-masing induk yang dipersilangkan. Heterosis akan mengalami maksimum apabila tetuanya tidak mempunyai hubungan kekerabatan yang dekat. Namun demikian persilangan akan menguntungkan apabila dibentuk dari galur-galur yang telah diadaptasikan dengan lingkungan yang diinginkan.

Terdapat interaksi antara heterosis dengan lingkungan di mana heterosis pada umumnya lebih besar jika individu tersebut dipelihara pada lingkungan

Tabel 4. Nilai heterosis $(\% \mathrm{H})$ dari sembilan persilangan antar strain pada tiga tingkat salinitas $0 \%, 10 \%$, dan $15 \%$

Table 4. Heterosis $(\% H)$ from nine crosses reared in three different salinities are $0 \%, 10 \%$, and $15 \%$

\begin{tabular}{|c|c|c|c|c|}
\hline o & $0 \%$ & $10 \%$ & $15 \%$ & Keterangan \\
\hline \multirow{4}{*}{$B$} & & G & & \\
\hline & 16.23 & 32.94 & 34.92 & Jantan \\
\hline & 20.21 & -0.68 & 13.58 & Betina \\
\hline & 18.22 & 16.13 & 24.25 & Rataan \\
\hline \multirow{4}{*}{ G } & & $M$ & & \\
\hline & 4.31 & -15.79 & 20.28 & Jantan \\
\hline & 0.23 & 55.42 & 8.52 & Betina \\
\hline & 2.27 & 19.82 & 14.40 & Rataan \\
\hline \multirow{4}{*}{$M$} & & B & & \\
\hline & 41.73 & 45.01 & 56.54 & Jantan \\
\hline & 46.61 & 44.36 & 58.43 & Betina \\
\hline & 44.17 & 44.68 & 57.49 & Rataan \\
\hline
\end{tabular}


yang buruk (15\%), seperti yang terlihat pada Tabel 4 . Oleh sebab itu, keunggulan heterosigot (heterozygot advantage) dapat dimaksimumkan pemanfaatannya jika dipelihara pada lingkungan yang marginal.

Daya gabung (combining ability) bukanlah suatu hasil yang tidak dapat diramalkan. Warwick et al. (1995) mengemukakan bahwa penampilan dari persilangan tergantung pada susunan genetik dari bangsa atau galur yang disilangkan. Jayaprakhas et al. (1988) menjelaskan juga bahwa jika heterosis untuk karakter pertumbuhan ditentukan oleh efek dominan, maka $F_{1}$ hybrid akan tumbuh lebih cepat karena heterosisnya besar. Sebaliknya Tave et al. (1990) menjelaskan bahwa jika faktor genetik antar strain atau galur yang disilangkan berbeda nyata, maka $F_{2}$ dan seterusnya akan tumbuh lebih cepat daripada $F_{1}$. Sebagai konsekuensinya, hasil program pemuliaan akan meningkat jika nilai keturunan dari parameter genetik yang ikut andil ke heterosis diketahui.

\section{KESIMPULAN}

Daya gabung gen (GCA) tertinggi pada semua salinitas dimiliki oleh genotipe GG dengan nilai 1.392 . Daya gabung khusus (SCA) maupun resiproknya yang tertinggi ditunjukkan oleh genotipe GM dengan nilai 0,57 dan 3,99. Persilangan Musi betina dan Barito jantan (MB) menghasilkan heterosis terbaik pada salinitas $15 \%$ o dengan nilai $57,49 \%$.

\section{DAFTAR PUSTAKA}

Aquacop. 1983. Intensive larval rearing in clear water of $M$. rosenbergii (de Man anuenue stocks) at Center Oceanologique du Pacifique, Tahiti, Handbook of Mariculture. Vol.1. Crustacean Aquaculture, p. 179-187.

Becker, W.A. 1984. Manual of Quantitative Genetics. Forth Edition. Published by Academic Enterprises, Pullman, Washington, p. 45-87.

Falconer, D.S. and T.F.C. Mackay. 1996. Introduction to Quantitative Genetics. $4^{\text {th }}$ Ed. Longman, Malaysia, 460 pp.

Hadie. L.E. dan W. Hadie. 1999. Efektivitas seleksi terhadap perbaikan mutu genetik udang galah. Prosiding Seminar Hasil Penelitian Genetika Ikan. INFIGRAD, Puslitbang Perikanan dan Dirjen.Perikanan.Deptan. Jakarta, p. 30-34.
Hardjosubroto, W. 1994. Aplikasi Pemuliabiakan Ternak di Lapangan. Gramedia Widiasarana Indonesia, Jakarta, $284 \mathrm{pp}$.

Jayaprakhas, V., D. Tave, and R.O. Smitherman. 1988. Growth of two strain Oreochromis niloticus ynd their $F_{1}, F_{2}$ and backcross hybrids. ICLARM Conference Proceeding, 15: 197-201.

Ling, S.W. 1969. The general biology and development of Macrobrachium rosenbergii (de Man). FAO World Sci. Conf. on the Biol. and Culture of Shrimp and Prawn, Mexico city, p. 9-21.

Mukerjee, T.K. 2001. Genetics for improvement of fish in Malaysia. International Network on Genetics in Aquaculture. ICLARM Conf. Proc. 64, 179 pp.

New, M.B. 1995. Status of freshwater prawn farming: A review. Aquaculture Research, 26 (1): 1-54.

Nugroho, E., A. Widiyati, Imron, dan T. Kadarini. 2003. Keragaan genetik ikan nila GIFT berdasarkan polimorfisme mitokondria DNA D-loop. J. Pen. Per. Indonesia. BRKP. edisi Akuakultur, 8(3): 7-12.

Nugroho, E., T. Kurniasih, W. Hadie, dan L.E. Hadie. 2004. Evaluasi Variasi Genetik Udang Galah GIMacro, Musi, dan Barito dengan menggunakan penciri DNA. Prosiding Hasil Penelitian Balai Riset Perikanan Budidaya Air Tawar, 9 pp.

Popper, O.M. and R. Davidson. 1981. An Experiment in Rearing Freswater Prawns in Brackish Water Polyculture. UNDP/FAO Bait Fish Project, Apia. Somoa, p. 245-146.

Singh, R.K. and B.D. Chaudhary. 1977. Biometrical Methods in Quantitative Genetic Analysis. Kalayani Publisher, New Delhi, p. 102-143.

Smith, T.I.J., P.A. Sandifer, and W.E. Jenkins. 1975. Growth and survival of prawn $M$. rosenbergii, pond reared at different salinities. International Conference on Macrobrachium Farming, p. 309-328.

Tave, D. 1986. Genetics for Fish Hatchery Manager. AVI Publishing Co. Inc. Westport, Connecticut.

Tave, D. 1996. Selective breeding programmes for medium-sized fish farms. FAO Fisheries technical Paper. 352. Rome, 122 pp.

Tave, D., R.O. Smitherman., V. Jayaprakhas., and D.L. Kuhler. 1990. Estimate of additive genetics effects, mathernal genetics effects, individual heterosis, maternal heterosis, and egg cytoplasmic effects for growth in Tilapia nilotica. J. Of The World Aquaculture Society. 21(4): 263-270.

Warwick, E.J., J.M. Astuti, dan W. Hardjosubroto. 1995. Pemuliaan Ternak. Gadjah Mada University Press, Yogyakarta, $485 \mathrm{pp}$. 